\title{
Analysis of Digital Marketing Processes to Improve Business Performance: Foods and Beverages MSMEs in Indonesia
}

\author{
Elvita Laurensia Santoso, Walda Vivian, Sekar Wulan Prasetyaningtyas \\ MM Young Professional Business Management, Bina Nusantara University, Tangerang, \\ Indonesia \\ Email: Elvita.santoso@binus.ac.id, Walda.vivian@binus.ac.id, Sekar.p@binus.edu
}

\section{ARTICLE INFO}

Received: 08-01-2022

Revision: 13-01-2022

Received : 20-01-2022

Keywords:

Business performance;

digital marketing

processes; foods and

beverages; Indonesia;

MSMEs

\section{ABSTRACT}

In this era, the way people do business has switched to digital marketing. Accordingly, the purpose of this research is to find out the right digital marketing processes to improve business performance, with a focus on foods and beverages MSMEs in Semarang, Indonesia, motivated by the growth of digital marketing implemented by business owners. This research paper is based on a qualitative approach with a descriptive research method and used literature review, interviews, and observation to collect the data. This research examines the digital marketing processes of foods and beverages MSMEs in Semarang, which has rarely been focused on, and reveals that MSMEs that carried out more complete digital marketing processes have the potential to improve business performance.

\section{Introduction}

shifting. Based on research conducted by

In the current era of 4.0 , people's way of life has begun to be influenced by technology, especially the internet. The development of the internet encourages people to do activities through digital, starting from how to socialize, take education, and do business. This statement is supported by (Gumilang, 2019), which states that the use of digital affects supporting people's businesses, especially in promoting and marketing, starting from businesses on the MSMEs scale (Micro, Small and Medium Enterprises) until large-scale businesses. (Haryanti, Mursito, \& Sudarwati, 2019), also stated that marketing activities in this era are not only be done traditionally but also with modern methods by using the internet. Based on those explanations, it can be proven that digitalization has affected the way people do marketing, which started to switch to digital. Business owners in Semarang, Indonesia, especially MSMEs, have also experienced that
Novita (2020), (Purwana, Rahmi, \& Aditya, 2017), and (Pradiani, 2017), these businesspeople admitted that after doing digital marketing, their MSMEs business's brand awareness and sales volume were increased, this result also in line with increasing of the customers. On the other side, based on research conducted by Barreda, Nusair, Wang, Okumus, and Bilgihan, (2020) found that digital marketing has a positive impact on the brand's image of the company. Based on these results, Ayosemarang.com (2020), stated that MSMEs owners in Semarang are encouraged to use digital marketing, especially due to the COVID-19 pandemic. The data contained in Kominfo (2017) also supports this statement, which stated that now MSMEs business owners in Semarang are also starting to expand the market through online platforms.

In addition, Semarang is also known as the city of MSMEs. This is supported by data

\footnotetext{
How To Cite:

Santoso, E. L., Walda Vivian, Sekar Wulan Prasetyaningtyas. (2022). Analysis of Digital Marketing Processes to Improve Business Performance: Foods and Beverages MSMEs in Indonesia. Journal of Social Science, 3(1), https://doi.org/10.46799/jss.v3i1.289

E-Issn: 2721-5202

Published By: Ridwan Institut
} 
submitted by Suaramerdeka.com (2019), which stated that Semarang is getting closer to establishing itself as a city of MSMEs in 2020, where Semarang is the first area in Indonesia to have the greatest number of MSMEs permits, with a total of 16,597 MSMEs registered and has a micro and small business license (IUMK). This number has increased ten times compared to the previous years. In addition, Suaramerdeka.com (2019), also said that the Mayor of Semarang, Hendrar Prihadi, officially launched Gerai Kopi dan Mi (Gerakan Terintegrasi Koperasi dan Usaha Mikro) program, to support the integration of MSMEs business owners in Semarang, by providing 699 healthy cooperations. This integration was expected to improve MSMEs in Semarang.

Meanwhile, based on data submitted by (Wahyudi, Utomo, \& Mariana, 2019), the type of MSMEs business in Semarang is dominated by processed foods, with a total of 4,282 MSMEs. Along with this, according to IDN Times (2019), Semarang is also known as the city of lumpia and jamu, which shows that Semarang is one of the cities that contributes and has attractiveness in foods and beverages.

Many previous researchers have discussed about digital marketing of MSMEs such as research conducted by Novita (2020), (Purwana et al., 2017), (Pradiani, 2017), (Felicia, 2015) and (Gumilang, 2019), but previous research only focused on implementation, utilization, or the influence of digital marketing, but not many researchers have discussed about the digital marketing processes more deeply. The digital marketing processes have been discussed by (Pradiani, 2017) and (Gumilang, 2019), but (Pradiani, 2017) did not discuss this topic specifically, because she used a quantitative approach, which focused on discussing the effects of digital marketing, while (Gumilang, 2019) research used a qualitative approach, but only discussed the processes in the literature review section, while in the discussion section, he only focused on the strategy or media used. Meanwhile, Novita (2020), as well as (Purwana et al., 2017), focused more on the implementation and use of digital marketing rather than the processes.

This is very unfortunate because according to (Chaffey, Edmundson-Bird, and Hemphill (2019), in doing digital marketing, there are various processes that are very important in supporting strategy and improving business performance, even these processes have the greatest effect on the success of digital marketing, so it is necessary for business owners to know and apply the processes.

On the other hand, researchers decided to focus on digital marketing processes to improve business performance because according to Strauss and Frost (in (Pradiani, 2017), digital marketing strategies have impacts in some aspects, such as increasing sales, market share, awareness, and so on. So, the conclusion is the researchers are interested to research on the digital marketing processes to improve the business performance of foods and beverages MSMEs in Semarang, Indonesia.

\section{Digital Marketing}

According to Novita (2020), nowadays, marketing is no longer carried out conventionally, where buyers should meet with sellers directly. With technological developments, buying and selling transactions including marketing activities can be done digitally. The theory said by Novita (2020) is in line with the results of research obtained by (Pradiani, 2017) and (Gumilang, 2019), which stated that digital marketing is the result of the adoption of technological developments from traditional to digital forms. Meanwhile, (Krisnawati, Ubaidi, Rais, \& Batu, 2019) have a different perspective about digital marketing. In their opinion, digital marketing is not only talking about changes in promotional methods but also changes in forms of interaction, where now consumers can participate or modify the content and the information they receive (two 
ways). This opinion is also supported by (Purwana et al., 2017), who think digital marketing not only in terms of promotion, but also from the interactions that happened through available media, such as blogs, websites, e-mail, and social media.

Other than that, (Liesander \& Dharmayanti, 2017) said that there are several dimensions related to digital marketing, which consist of design and content, as well as customer relationship management (CRM). Design and content in digital marketing are displays, visualizations, and materials, so they can provide positive value for businesses. Meanwhile, relationship management with customers (CRM) is a relationship that exists between business owners and customers, so that information can be delivered properly and build customer loyalty. Meanwhile, according to (Gumilang, 2019), the dimension related to digital marketing is the platform. The platform is a forum where companies can meet and share information with customers through the internet. In addition, to the opinion said by (Ompusunggu, 2018) , the important dimension in digital marketing is promotional activities. Promotional activity is a program or activity that is used to promote or introduce a product, in order to gain long-term benefits. Besides the digital marketing theories that have been explained above, there are also digital marketing processes that should be done by business owners.

\section{Digital Marketing Processes}

According to (Chaffey et al., 2019), digital marketing processes are described in the scheme below:

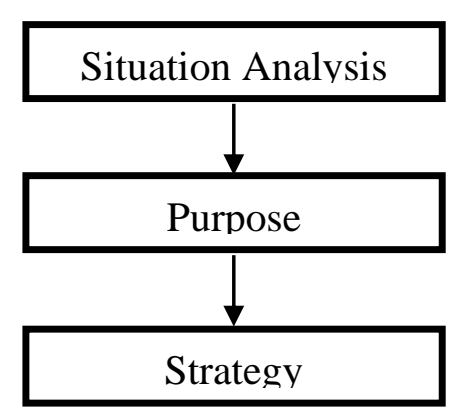

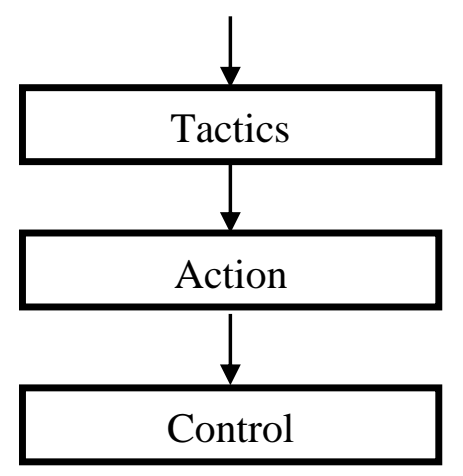

Figures 1. Digital Marketing Processes

Situation analysis is carried out to understand the current and future environment, which can help the company in making realistic and strategic objectives toward what is happening in the market share. Situation analysis consists of Customer Opinion, SWOT Analysis, Perception of Brands, Capabilities, and Internal Resources. Purpose consists of the $5 \mathrm{~S}$ objectives, such as Sell (customer acquisition and retention target), Serve (customer satisfaction target), Sizzle (intensity and duration of the site), Speak (how many brands are spoken by other people and the number of customers involved), Save (efficiency gains are achieved). Strategy defines how digital marketing goals will be achieved. It is done by carrying out several stages, such as: (1) Determine segmentation, targeting, and positioning; (2) OVP (Online Value Proposition); (3) Sequence (credibility before visibility); (4) Tools (website, email, social media, etc). Meanwhile, Tactics consists of (1) Digital Marketing Mix (4P / 7P - Product, Price, Promotion, Place, People, Process, Physical Evidence); (2) Content Strategy; (3) E-campaign; (4) Online Branding (Brand Equity and Identity). Action is an activity carried out to execute a plan. It consists of managing the division of tasks and structure, recruiting resources, partnering, outsourcing, and budgeting. Based on Strauss and Frost (in Pradiani, 2017), when the business owners did the budgeting step, they should monitor the actual revenue and expenses to 
see what results have been achieved. Control can be achieved through marketing research and website analysis to monitor whether the company's goals are being achieved, which is measured by creating KPIs, doing customer satisfaction surveys, and seeing the number of visitors. According to (Chaffey et al., 2019), it can be said that digital marketing processes play many important roles in supporting the success of digital marketing.

\section{Business Performance}

Digital marketing is seen as the best, effective, and efficient medium for promotion and can improve business performance, such as increasing sales, customers, and awareness (Gumilang, 2019). This opinion is also supported by (Krisnawati et al., 2019), who stated that digital marketing plays a positive role to increase some business aspects, especially increasing sales. Based on research conducted by (Pradiani, 2017), by doing digital marketing, the increment in sales has even reached an average of up to $100 \%$, which in line with increasing the number of customers. This is because the use of digital marketing can reach a wider market, build closer relationships with customers, and simplify the buying and selling processes (Haryanti et al., 2019). The success in the use of digital marketing must be followed using an appropriate platform, the right strategy, the use of analytical tools to find out customer needs, appropriate and consistent marketing contents. All these stages can have an impact on building brand awareness which leads to increase sales (Lockett, 2018). Therefore, to improve business performance, business owners must know the right processes for doing digital marketing.

According to (Kurdi, 2018), there are several dimensions related to improving business performance, such as sales volume, company profit, and company growth. Sales volume is all sales generated by the company within a certain period. Company profit is collected by subtracting the net sales of the company from expenses. Company growth is measured by an increase in the number of customers, customers involved, and visitors in the platform of a business.

\section{Method}

This study uses a research method with a qualitative approach. The reason researchers chose the qualitative approach is because it needs deeper exploration through every digital marketing processes, by knowing the perspective from foods and beverages MSMEs business owners in Semarang, and how these processes have an impact on improving business performance. This study also uses the descriptive research method, intending to describe and provide a complete and accurate picture of the digital marketing processes in improving business performance. This research was conducted through observation, interviews, and documentation of foods and beverages MSMEs business owners in Semarang, which was conducted to obtain primary data. The research strategies were carried out online which started in March 2021, due to the COVID-19 pandemic. In this study, the study setting chosen by the researchers were the non-contrive study, where the research will be carried out with real observation in the field, without changing any element. Units' analysis of this research are MSMEs business owners because the researchers want to find out every perspective of business owners.

In this study, researchers use a crosssectional time horizon, because the researchers want to get the results of the research simultaneously within a certain period. The subjects in this study are 5 foods and beverages MSMEs business owners with certain criteria, which will be explained in the "population and sample" section. The reason the researchers chose 5 business owners is because the researchers felt that the five business owners can provide maximum information, according to the data the researchers needed. In addition to this, according to (McCusker \& Gunaydin, 2015), 
qualitative research is based on the quality of informants' responses to the questions and is not based on statistical calculations or the number of informants. In its practice, the number of informants will be adjusted, according to the completeness of the data obtained. If the results obtained have not found a saturation point (there are still variations of answers), the research will continue by adding the number of informants. Otherwise, if the answer has found a similarity, the addition of informants will be stopped. Meanwhile, the objects in this study are digital marketing, digital marketing processes, and business performance. The location of this research is in Semarang. In this study, the primary data was obtained by researchers by conducting interviews, observations, and documentation of business owners. Meanwhile, secondary data is obtained by collecting information through several sources of books or literature studies, previous research, and online data search.

Data collection methods used in this study consist of (1) Interviews. In practice, the type of interview used by researchers is semi-structured interviews. The interview was aimed to find deeper problems. In this type of interview, the researcher makes interview guidelines, but the questions asked were more flexible, according to the answers given by the informants. The interviews will be conducted online via Skype or Whatsapp Video Calls. The reasons why the researchers chose the semi-structured interview method is to know the experiences and perceptions of each informant regarding the digital marketing processes that have been done; (2) Observation. In conducting the observation method, the researchers observed the platform where MSMEs business owners carried out the digital marketing processes, the goal is to find out whether the digital marketing processes on the platform have been running well or not, and whether the business performance has improved or not; (3) Documentation. In practice, the researchers took a photo together with the informants and made the interview transcript to support the accuracy of the data; (4) Document Checking. Researchers checked documents to determine the percentage of increase in sales, net income, and volume owned by the business owners. The populations in this study are all of foods and beverages MSMEs business owners in Semarang. This study uses non-probability sampling with a purposive sampling technique. Purposive sampling is a sampling technique with consideration of certain

criteria. Therefore, some of the criteria chosen by the researchers were:

(1) MSMEs business owners in foods and beverages; (2) Has been in business for at least 1 year; (3) Domicile in Semarang; (4) Has been doing digital marketing, for at least 1 year.

Based on the criteria above, the researchers chose 5 foods and beverages MSMEs business owners in Semarang, as follows on Table 1.

Table 1

Intervew

\begin{tabular}{ccl}
\hline Informant & Scope of business & \multicolumn{1}{c}{ Profil } \\
\hline Informant 1 & Geprek Chicken Restaurant & Male, Adult, started the business in 2016 (5 years) \\
\hline Informant 2 & Sego Babat Restaurant & $\begin{array}{l}\text { Female, Young Adult, started the business in 2018 (3 } \\
\text { years) }\end{array}$ \\
\hline Informant 3 & Japanese Foods & $\begin{array}{l}\text { Male, Young Adult, started the business in 2020 (1 } \\
\text { year) }\end{array}$ \\
\hline Informant 4 & Coffee Shop & $\begin{array}{l}\text { Male, Young Adult, started the business in 2019 (2 } \\
\text { years) }\end{array}$ \\
\hline Informant 5 & Chicken Rice Box & Male, Adult, started the business in 2018 (3 years) \\
\hline
\end{tabular}


The reason why researchers chose the purposive sampling technique is because the researchers need certain criteria in determining the research sample so that the results are obtained specifically. On the other hand, this study uses data processing and analysis techniques based on the Miles and Huberman model. Activities in data analysis are divided into (1) Data Collection, in this activity, the researchers conducted a general search, by collecting data from literature studies, online data searches, interviews, observations, and documentation; (2) Data Reduction, in carrying out the reduction activity, the researchers recapitulated the data using a computer / PC by only selecting some data related to the topic and being able to answer the problems. This stage is carried out to eliminate information that is irrelevant to the research topic; (3) Data Presentation; researchers connected the results of research with literature reviews by previous researchers and theories, so that the research results are detailed and could answer existing problems; (4) Data Verification, after presenting the data, the researchers concluded the data that can be used to answer the problems and give recommendations for further researches, related to the digital marketing processes. The data validity technique used by the researcher is the degree of trust, especially by using the triangulation technique. Denzin (in Moleong, 2013) divided triangulation into four parts, such as triangulation of sources, methods, investigators, and theories. The types of triangulations used by researchers were, (1) Triangulation Method, in this study, researchers used several data collection methods such as interviews, observation, documentation, and document checking to check data; (2) Triangulation Theory, in this type of triangulation, the researchers connected the findings with digital marketing processes and other theories that explained in the introduction section.

\section{Results And Discussion}

Digital marketing of food and baverage in Indonesia has been varied and tried to implementing various digital platform to marketing the products although it is not occured oftenly.

After conducted interviews, observing, and checking documents methods with the five informants, the following research results were obtained:

\section{Digital Marketing Processes}

From the results of interviews and observations, the 5 informants have carried out several existing digital marketing processes that in line with theories stated by (Chaffey et al., 2019). The processes carried out are divided into:

(1) Situation Analysis

The situation analysis consists of:

- Internal capabilities and resources

All informants agreed that they have analyzed the capabilities of internal resources before carrying out the digital marketing processes, both from the capabilities of management and the resources they had (such as digital marketing planning, the team they had, and so on). This internal analysis can result in the company's SWOT, which will be described in the next section.

- SWOT analysis

All informants have also conducted a SWOT analysis before carrying out the digital marketing processes, where informants 1-5 have known the strengths of their business, compare to its competitors. By knowing their strengths, they also created a unique selling proposition that can be offered to overcome existing weaknesses and threats and take full advantage of opportunities.

- Customer's opinions

1 of 5 informants (informant 4) has done this process. Meanwhile, 4 other informants have not done this process when doing digital marketing for the first time. The four informants immediately carried out trial and error, without 
considering the approximate opinion that the customer had previously conveyed. From the results of observations about the number of followers on Instagram, researchers found that informant 4 has the highest number of followers $(2,008$ followers), compared to the other 4 MSMEs, thus proving that customers' opinions need to be considered before doing digital marketing. The reason is because customers opinions also affect the quality of the contents that the company served, where informant 4 has more interesting and consistent contents (use pastel, gray tone and manner), that are different from its competitors, and relevant to its target customers (millennial to 50 years). On the other side, informant 4 also uses koala mascot to make its brand easy to remember especially by Millenials.

- Perception of Brands

1 of 5 informants (informant 2) has not considered the perceptions that the public wants to have on the brand and immediately carried out trial and error, while the other four informants have considered that perception. Informant 1 wants to build its image as a fun and friendly place to eat. Informant 3 wants to build its image as a Japanese food with provide various sauces and using Japanese kanji on Instagram. Informant 4 wants to build an image as a provider of healthy drinks and relevant to young people, by providing and promoting menus containing natural ingredients, such as honey and coconut water, and eye-catching packaging with an interesting tone and manner. Informant 5 wants to build an image as food that can be enjoyed at any time by various people that easy to carry everywhere, by making simple packaging, informants 5 also involves talent for photos from all ages (parents to young people).

(2) Purpose
All informants have objectives to be achieved when doing digital marketing. The objectives consist of:

- Sell

All the informants have the same objective to increase customers and sales. This can be proven by the type of contents that they served, such as discount promotional contents and photos of products. 4 out of 5 informants (except informant 3) have also collaborated with $\mathrm{KOL}$ and the food community to increase sales.

- Serve

All the informants have the same objective to increase customer satisfaction, by answering customer comments, responding to any questions, or directly providing solutions if there were problems.

- Sizzle

4 of 5 informants (except informant 2) have an objective to increase the intensity of customers who visit and follow their social media. Informant 1 , Informant 3 , and Informant 5 have created holiday greeting contents to increase the intensity of visits from customers. Informant 3 and Informant 4 have also created a community to build relationships with customers. Informant 4 has community on Instagram, and Informant 5 has created a community of coffee lovers, vape, and cute drink lovers for women.

- Speak

1 of 5 informants (informants 4) has an objective to make their business are known and discussed by others, by having a tone of voice that $70 \%$ of their ingredients are healthy and natural, and people can change their drinks to be healthier. Besides that, informant 4 also provides creative and interesting contents, so their customers, especially young people, can be interested and talk about their brand to their closest relatives.

- Save 
1 of 5 informants (informant 3) has an objective to minimize costs to be more efficient, by using digital marketing, so that they can reach a wider target with minimum possible cost.

(3) Strategy

All informants have a strategy that is carried out to achieve the goals of digital marketing, which consists of:

- Determine segmentation, targeting, and positioning

All informants have not yet determined the segmentation of their business, but the target market and business positioning have been determined by all informants specifically. Informant 1 targeted Diponegoro University students aged $18-23$ years at first, then expanding their target by reaching employees and parents up to the age of 43 years. Informant 1 has a positioning as a friend of the customers who is friendly and fun, which is shown through the language in the caption or when responding to customers. Informant 2 has targets from college students to parents aged 18-45 years, groups of people who like to try new foods such as Madurese foods, and groups of people who like to find places that are instragrammable because the design of their restaurant looks like Majapahit Kingdom. Informant 2 has a positioning as the only Madurese Sego Babat provider in Semarang. Informant 3 targeted all ages and groups, but prioritized families and Japanese food enthusiasts. Informant 3 has a positioning as a family-friendly Japanese restaurant that everyone can enjoy. Informant 4 targeted SES A-C people aged $18-50$ years, groups of people who are looking for healthy and cute foods and drinks, and groups of people who like to hang out or drink coffee. Informant 4 has a positioning as a provider of healthy drinks with unique and aesthetic packaging. Informant 5 targets people aged 18-45 years old with its positioning as daily edible food in any situation.

- OVP (Online Value Proposition)

From the research results, it can be found that informants 1-5 have their uniqueness to add OVP to their brands. OVP of informant 1 is they use slang language on social media, the unique nickname so that it has an image as a friendly and funny brand, and photos of food products. Meanwhile, informant 2 also presented photos of tantalizing food products as their OVP. Informant 3 has community and specific tone and manner, such as red, black, and white, and using Japanese kanji characters. Informant 4 presented aesthetic photos of products, had a koala mascot, pastel, monochromatic tone and manner. Informant 5 provides photos of products, video reviews from influencers, real photos from customers, Grab, Go-jek, and carries out discount promotions.

- Sequence (credibility before visibility)

All of the informants strive to provide the best quality of foods and drinks with the uniqueness of their businesses, such as informant 1 provides saus brewok (sauce with sweet-spicy taste), which is different from the sauce on usual geprek chicken, informant 2 provides sego babat of Madurese, informant 3 provides Japanese foods with a choice of various sauces, informant 4 provides foods and drinks with healthy ingredients, and informant 5 provides rice boxes with simple packaging that can be carried everywhere and zero waste because there are no chicken's bones. In addition, all the informants also provide the best services on offline and online stores on social media, such as providing quick responses when there were complaints and questions from customers.

- Tools used

All the informants are using social
media Facebook, Instagram, and
Whatsapp, as well as GoFood and


GrabFood in marketing their products. In addition, informant 1 also used Line but it is starting to be rarely used, informant 3 using Tokopedia and Twitter, while informant 4 plans to use Tiktok to keep up with trends.

(4) Tactics

Consists of:

- Digital Marketing Mix

To achieve marketing goals in the targeted market, all informants have used a digital marketing mix, with the following explanations:

Informant 1 has a geprek chicken product with saus Brewok that is unique and different from its competitors. The price of the foods offered starts from Rp. 15,000 - Rp. 22,500, and the price of the drinks offered starts from Rp. 3,000 - Rp. 6,500 . However, related to the place, it has a place that is quite strategic and comfortable but does not have any specialty compared to its competitors. To solve this problem, informant 1 is doing promotion by highlighting saus brewok, giving discount promotions, photos of food products, and the atmosphere of the place to eat, along with captions that are friendly and relevant to young people.

Informant 2 is the only brand that serves Madurese sego babat products in Semarang. The price of the foods offered starts from $\operatorname{Rp~18,000-Rp~28,000.~One~of~}$ the uniqueness of their restaurant is it provides a place to eat with the atmosphere of Majapahit Kingdom. So far, the promotions carried out by them are discount promotions, photos of food products, and video reviews from food bloggers.

Informant 3 has Japanese food products such as katsu, karagee, and rice bowls served with various types of sauces. The price of the foods offered starts from Rp 13,200 - Rp 32,400. The place offered by them is quite comfortable with a semioutdoor design. However, the promotions carried out by them are quite limited by carrying out discount promotions, photos of food products, and the atmosphere of the place to eat.

Informant 4 has food and beverage products with aesthetic packaging and uses $70 \%$ natural ingredients. The price of the drinks offered starts from Rp 18,000 Rp 60,000 and the foods start from Rp

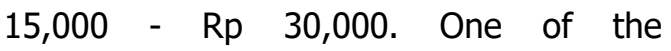
advantages that they have is a unique place with a monochromatic design, which is perfect for being a photo spot for millennials. The type of promotion offered by them is a photo of foods and beverages products that are very creative and aesthetic.

Informant 5 has food and beverage products of chicken rice boxes with simple packaging that can be carried anywhere. The price of the drinks offered starts from Rp. 5,000 - Rp. 23,000 and the food start from Rp. 22,500 - Rp. 54,000. They have a comfortable place with indoor and outdoor options, but it doesn't have any specialty compared to its competitors. The types of promotions offered by them are photos of food products, discount promotions, video reviews from food bloggers, real photos of customers, and Gojek / Grab.

- Content Strategy

The strategies of the informants in providing content of digital marketing are as follows:

Informant 1 has contents such as holiday greetings, discount promotions, photos of products, the atmosphere of the place to eat, testimonials, and information about their restaurant. Informant 2 has contents such as photos of products, video reviews from food bloggers, information about their restaurant, and testimonials. Informant 3 has contents such as holiday greetings, engagement content in the form of quizzes, discount promotions, collaborations with brands, photos of products, dining atmosphere, testimonials, and information about their restaurant. 
Informant 4 has contents such as photos of products, testimonials, engagements, and information about their coffee shop. Informant 5 has contents such as holiday greetings, discount promotions, video reviews from food bloggers, photos of products, the atmosphere of the place, testimonials, and information about their restaurant. Besides of contents above, 2 out of 5 informants (informants 3 and 4) also made a tone and manner to increase public interest in their social media. Informant 3's tone and manner are red, white, and black. Meanwhile, informant 4 has a tone and manner of pastel and gray colors.

- E-campaign

On social media, 1 in 5 informants (informant 3) have conducted an ecampaign to distribute free food every Friday for underprivileged people.

- Online Branding

All the informants have done Online Branding on social media in accordance with the Online Value Proposition they have.

(5) Action

In executing the entire digital marketing processes, the five informants have carried out activities such as managing the division of tasks and structures, recruiting resources, partnering, outsourcing, and budgeting. The explanations are as follows:

Informant 1 divided the tasks that consisting of 3 people, with the following tasks: 1 person is responsible for operational activities and human resources, 1 person is responsible for marketing and design for social media, and 1 person is responsible for semi-chef, research, and development. Informant 2 did not have any division of tasks or outsourcing, all digital marketing activities are carried out by the owner, while operational activities are assisted by a chef and several waiters. Informant 3 divided the tasks that consisting of 3 people, with the following tasks: 1 person is responsible for finances, 1 person is responsible for marketing and operational activities, and 1 person is the head of the kitchen, research, and development. Informant 4 has a division of tasks consisting of 2 people to handle operational activities and general marketing strategies. Meanwhile, they have partnered for designing content design and taking photos of products. Informant 5, all tasks are done by the owner, assisted by several waiters and chefs. Regarding to do digital marketing, they outsource the worker to design, make contents, and take photos of products.

In addition, all informants also make a budget each year to estimate the money spent on all operational and marketing activities. Informant 1 issued a digital marketing budget of $\mathrm{Rp} 500,000$ - Rp $1,000,000$, informant 2 issued a digital

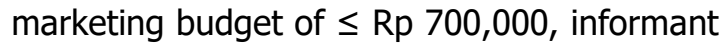
3 issued a digital marketing budget of Rp 500,000, informant 4 issued a digital marketing budget of $\mathrm{Rp} \mathrm{1,000,000} \mathrm{-} \mathrm{Rp}$ $3,000,000$, informant 5 issued a digital

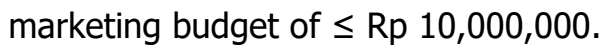

(6) Control

All informants agreed that they evaluated carrying out the digital marketing processes. Informant 1 evaluates once a month and after the events by looking to the insights section on social media (to find out reach), increment of followers and sales. Informant 2 evaluates once a month by looking to the insights section on social media (to find out the reach), number of sales, and making a list of food bloggers who have collaborated with for further consideration. Informant 3 conducts evaluations twice a month every mid and at the end of the month by evaluating the whole team and conducting discussions per area to find out what needs to be maintained and changed. Informant 4 conducts evaluations after advertising contents on social media, by seeing how many its reach and providing an evaluation form to customers who came to the offline store. Informant 5 conducts evaluations once 
a month by seeing the increment of sales, followers, and reach on social media.

Based on the elaboration of the processes explained above, all informants have started to carry out the stages of the digital marketing processes, even though some of the informants did not do the entire processes. Digital marketing processes should be done repeatedly during digital marketing.

\section{Business Performance}

All the informants agreed that carrying out the digital marketing processes could improve business performance, especially increasing customers and sales. This is also proven by the results of interviews and observations of the five informants. In 2021, Informant 1 had an increase in customers and sales of $10 \%$. Informant 2 had a $30-70 \%$ increase in customers, followed by a $30-40 \%$ increase in sales. Informant 3 had a $40-50 \%$ increase in customers followed by a $15-20 \%$ increase in sales. Informant 4 had an increase in customers and sales of $150-200 \%$. Informant 5 had a $20 \%$ increase in customers, followed by a $30 \%$ increase in sales.

Based on the explanations above, the percentage of the sales increment is balanced with the digital marketing processes that were carried out. Informant 4 has the highest percentage of the sales increment which is comparable with the completeness of the processes that it carried out, starting from research to the control (evaluation) stage. The success of the digital marketing process is because they considered the perceptions of the customers, starting from using mascot until distributing the evaluation forms. This is also proven by the number of their followers on Instagram as many as 2,008 followers. Meanwhile, in second place there is Informant 2. Even though they didn't do the entire digital marketing processes but they have their uniqueness to do digital marketing compared to its competitors, such as presenting interesting Sego Babat foods through photos, video reviews from food bloggers, and have a place with the atmosphere of Majapahit Kingdom. This is also proven by the number of followers that informant 2 has on Instagram as many as 1,937 followers.

On the other hand, Informant 3 is in third place. This is because they carried out the processes of tactics optimally, starting from holding e-campaign until made community, and presenting interesting tones and manners. However, the number of followers on Instagram has only reached 549 followers because they just started using digital marketing in 2020. Meanwhile, the other four MSME had started using digital marketing from 2016-2019. Besides that, Informant 5 is in fourth place. This is because the digital processes carried out have not been done completely and optimally, compared to the other four informants. This is also proven by the number of their followers on Instagram, which only reached 669 followers, even though they have been doing digital marketing since 2019, and this is also recognized by the owner who stated that he did not understand digital marketing processes that must be done. In the last place, there is Informant 1 . The processes carried out are quite good because they have a unique nickname. This is proven by the number of their followers on Instagram that reached 1,071 followers. However, the increase in sales is not too significant due to the Covid-19 pandemic, where customers who previously consisted of students have decreased, due to the absence of direct teaching and learning activities.

Based on the various descriptions above, it can be proven that MSMEs, which carried out comprehensive and unique digital marketing processes, gained a more significant increase in sales, customers, and even awareness that measured by the increment of followers on social media which can improve overall business performance. These results also in line with research that conducted by (Gumilang, 2019). One of the informants (Informant 4) already conducted almost all the processes which leads to the 
success of their digital marketing. This result also in line with the theories stated by (Lockett, 2018) that said the success in the use of digital marketing must be followed by the use of an appropriate platform, the right strategy, the use of analytical tools to find out customer needs, appropriate and consistent marketing contents. Informant 4 uses the right platform (Instagram) that suits its target market, does some strategies to answer the customer needs such as making contents that are relevant to Millenials.

\section{Conclusion}

After doing the observations and interviews with five foods and beverages MSMEs business owners in Semarang, Indonesia, it can conclude that to achieve the success of digital marketing, every business owner must consider all the digital marketing processes that have been mentioned above, such as situation analysis, purpose, strategies, tactics, action, and control. Through this research, it can be proved that the business owners who did the comprehensive and unique digital marketing processes improved their business performance by gaining a significant increase in sales, customers, awareness, and followers on social media.

\section{References}

Barreda, Albert A., Nusair, Khaldoon, Wang, Youcheng, Okumus, Fevzi, \& Bilgihan, Anil. (2020). The impact of social media activities on brand image and emotional attachment: a case in the travel context. Journal of Hospitality and Tourism Technology. Google Scholar

Chaffey, Dave, Edmundson-Bird, David, \& Hemphill, Tanya. (2019). Digital business and e-commerce management. Pearson UK. Google Scholar

Felicia, S. Ferdinand, D. (2015). Analisis pengaruh market timing terhadap struktur modal perusahaan nonkeuangan yang terdaftar di Bursa Efek
Indonesia. Jurnal Administrasi Bisnis. Google Scholar

Gumilang, Risa Ratna. (2019). Implementasi Digital Marketing Terhadap Peningkatan Penjualan Hasil Home Industri. Coopetition: Jurnal IImiah Manajemen, 10(1), 9-14. Google Scholar

Haryanti, Sri, Mursito, Bambang, \& Sudarwati, Sudarwati. (2019). Analisis Strategi Pemasaran Digital Untuk Meningkatkan Penjualan Produk Batik Pada Pt. Danar Hadi Surakarta. Jurnal I/miah Edunomika, 3(01). Google Scholar

Krisnawati, Indah, Ubaidi, Ibnu Auf, Rais, Hanif, \& Batu, Reminta Lumban. (2019). Strategi digital marketing dalam perdagangan hasil tani untuk meningkatkan pendapatan Kabupaten Karawang. Jurnal IImiah Ekonomi Global Masa Kini, 10(2), 70-75. Google Scholar

Kurdi, Sulaiman. (n.d.). Pengaruh Bauran Pemasaran Terhadap Peningkatan Penjualan Pada Koperasi Jasa Keuangan Syariah di Kabupaten Kendal. BISE: Jurnal Pendidikan Bisnis Dan Ekonomi, 4(2), 26-40. Google Scholar

Liesander, Indra, \& Dharmayanti, Diah. (2017). Pengaruh digital marketing terhadap organizational performance dengan intellectual capital dan perceived quality sebagai variabel intervening pada industri hotel bintang lima di Jawa Timur. Jurnal Strategi Pemasaran, 2(4), 1-13. Google Scholar

Lockett, Asia. (2018). Online Marketing Strategies for Increasing Sales Revenues of Small Retail Businesses. Walden University. Google Scholar

McCusker, Kevin, \& Gunaydin, Sau. (2015). Research using qualitative, quantitative or mixed methods and choice based on the research. Perfusion, 30(7), 537-542. Google Scholar

Moleong, Lexy J. (2013). Metode Penelitian Kualitatif, Bandung: Remaja Rosdakarya. Mosal. Google Scholar 
Ompusunggu, W.C. (2018). Pengaruh Produk, Distribusi, dan Digital Marketing terhadap Minat Beli Album Musik Korea Pop. Thesis, Sanata Dharma University, Yogyakarta. Google Scholar

Pradiani, Theresia. (2017). Pengaruh sistem pemasaran digital marketing terhadap peningkatan volume penjualan hasil industri rumahan. Jurnal Ilmiah Bisnis Dan Ekonomi Asia, 11(2), 46-53. Google Scholar

Purwana, Dedi, Rahmi, R., \& Aditya, Shandy. (2017). Pemanfaatan Digital Marketing Bagi Usaha Mikro, Kecil, Dan Menengah
(UMKM) Di Kelurahan Malaka Sari, Duren Sawit. Jurnal Pemberdayaan Masyarakat Madani (JPMM), 1(1), 1-17. Google Scholar

Wahyudi, Eko Nur, Utomo, Agus Prasetyo, \& Mariana, Novita. (2019). Pengelompokan Jenis Usaha Umkm Kota Semarang Dalam Rangka Proses Pembinaan Dan Pendampingan Untuk Pengembangan Usaha Dengan Teknik Data Mining. Dinamik, 24(1), 13-20. Google Scholar

\section{Copyright holder :}

Elvita Laurensia Santoso, Walda Vivian, Sekar Wulan Prasetyaningtyas (2022)

First publication right :

Journal of Social Science

This article is licensed under:

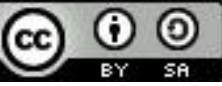

